\title{
EGFR Gene Mutation Negative
}

National Cancer Institute

\section{Source}

National Cancer Institute. EGFR Gene Mutation Negative. NCI Thesaurus. Code C148091.

A genetic finding indicating that EGFR gene mutations have not been detected in a sample. 